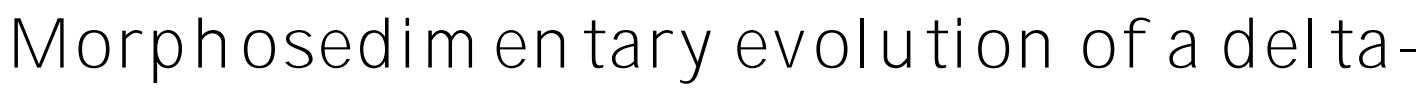 sourced, ఏlrift- aligned\$\$and[barrier-lagoon complex, [western BBight $[$ f $[$ Benin
}

Article[W [Marine[Geology:] une[1999

DOI:[10.1016/50025-3227(98)00170-4

CITATIONS

45
READS

157

2 authors, including:

\section{Edward[Anthony}

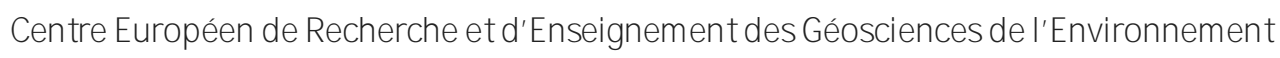

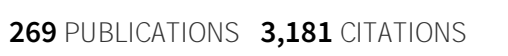

SEEPROFILE

Some of the authors of this publication are also working on these related projects:

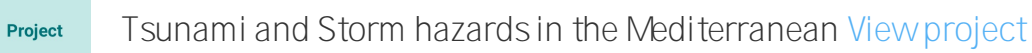

Project LADICIADiew project 


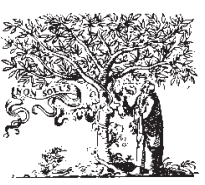

ELSEVIER

Marine Geology 158 (1999) 161-176

www.elsevier.com/locate/margeo

\title{
Morphosedimentary evolution of a delta-sourced, drift-aligned sand barrier-lagoon complex, western Bight of Benin
}

\author{
E.J. Anthony ${ }^{\mathrm{a}, *}$, A.B. Blivi ${ }^{\mathrm{b}}$ \\ a Université du Littoral 'Côte d'Opale', Département de Géographie, 2 Chaussée des Darses, \\ F-59140 Dunkerque, France \\ ${ }^{b}$ Département de Géographie, Université du Bénin, B.P. 1515, Lomé, Togo
}

Received 6 May 1998; accepted 25 September 1998

\begin{abstract}
The coast of eastern Ghana and Togo is bounded by a major Holocene sand barrier complex hinged on the Volta Delta to the west and subject to high rates of longshore sand drift $\left(1-1.5 \times 10^{6} \mathrm{~m}^{3} / \mathrm{yr}\right)$. In spite of its proximity to this major deltaic sediment source, this barrier system shows marked longshore variations in progradation following the middle Holocene eustatic stillstand. It is a 'hybrid' system in terms of internal facies composition and plan-view morphology, in that it has evolved from an essentially regressive to a stationary (synonymous with cessation of progradation) system. Both transgressive and barrier-inlet facies have also developed through time and space. These temporal and spatial changes in patterns of development reflect variations in longshore sand transport and deposition over the last 5000 years. Such variations have been controlled by sediment supply from the Volta, by antecedent topography, by lagoonal and river drainage, by sediment cell development and maturation, and in the very recent past, by anthropogenic perturbation. Barrier progradation in the western Bight of Benin diminished considerably or ceased probably as early as $3400 \mathrm{yr}$ B.P. as a single major equilibrium 'drift aligned' bight cell matured, permitting transport of Volta sand toward the rest of the eastern bight in Benin and Nigeria. The eastward longshore supply from the Volta has involved both direct inputs of upland-derived sand by the Volta river channel and reworking of nearshore deltaic deposits. A recent reduction in direct fluvial supply, exacerbated by the Akosombo Dam, completed in 1961, has induced a wave of erosion of the downdrift delta-mouth barrier and shoreface deposits to fulfil the strong drift requirements. In Togo, construction of a deepwater port in 1967 has also affected the barrier system. Both of these changes have had considerable impacts on longshore sediment dynamics. The most significant impact has been segmentation of the former unique sediment cell characterising the 400-km-long Bight of Benin coast, resulting in differential longshore erosion, progradation or equilibrium. These changes have also induced new patterns of barrier behaviour that include transgressive and regressive dynamics at various locations alongshore. (c) 1999 Elsevier Science B.V. All rights reserved.
\end{abstract}

Keywords: barrier stratigraphy; inlet; longshore drift; sediment cells; Volta Delta; West Africa

*Corresponding author. Fax: 333286615 69. E-mail:anthony@univ-littoral.fr 


\section{Introduction}

The facies stacking pattern on barrier coasts is commonly hinged on long-term (hundreds to thousands of years) sea-level changes (e.g., Thom, 1984a; Reinson, 1984; Galloway and Hobday, 1985; Davis, 1994) that determine the rhythm of transgression and shoreline translation across potential sediment sources. Sediment supply and varying sediment budgets may, however, constitute influential sources of barrier change in all stages of barrier development, and especially at short to medium time scales (tens to hundreds of years). Sediment budgets at such short to medium time scales may be considered within the framework of two useful concepts that provide a basis for formalising ideas of morphosedimentary changes on wave-dominated coasts.

Davies (1980) proposed the distinction between swash-aligned coasts, where sediment transport gradients alongshore are extremely weak, and driftaligned coasts, subject to more or less strong gradients in wave-induced drift. Especially on open coasts subject to changing wave approach directions and sediment supply, barrier systems may exhibit in time and space both drift- and swash-alignments as they strive to achieve equilibrium with the wave field. The other interesting concept for formalising sediment budget dynamics has been the now increasingly used coastal sediment cell (May and Tanner, 1973). Changes in cell dynamics are commonly associated with sediment budget variations that may result in the destabilization of barrier deposits, inducing generally large-scale morphosedimentary reorganization. Reorganization may commonly involve changes in barrier orientation, expressed by truncation and redeposition, with, in rare cases, wholesale switches from drift- to swash-alignment, or vice versa.

The coast of eastern Ghana and Togo (Fig. 1) is part of a major regional sand barrier complex in the Gulf of Guinea. This sand barrier coast is also subject to one of the highest rates of longshore drift in the world. In spite of its direct attachment to a major sediment source, the Volta Delta (Fig. 2), this coast shows marked temporal longshore and shore-normal variations in barrier progradation since regional sea level stabilised at about 5500 yr B.P. We show that changes in patterns of sediment supply and distribution alongshore, induced by various environmental factors, and by recent human activities, have resulted in the development of a 'hybrid' barrier system comprising regressive (progradational) and transgressive

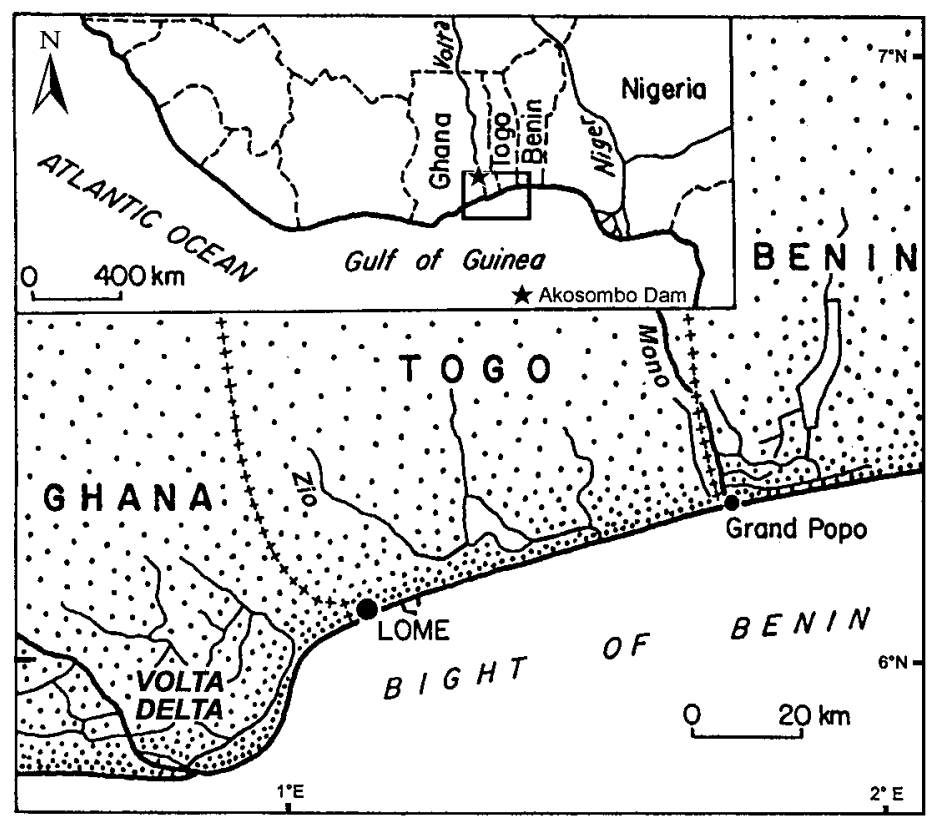

Fig. 1. Regional setting of the western Bight of Benin. 
elements as well as tidal inlet reworking. The most recent changes are related to dam and port construction. They have resulted in the segmentation of a hitherto major single drift-aligned sediment cell characterising this $400-\mathrm{km}$-long bight coast, inducing longshore alternations of eroding and prograding sectors associated with local changes in shallow barrier morphostratigraphy.

\section{Methods}

Interpretation of barrier-lagoon morphosedimentary history has involved a variety of approaches embracing various time scales. The plan-view barrier patterns were mapped from various sources, notably old coverages of aerial photographs, and topographic and geological maps. A special cover of infrared colour photographs at a scale of 1:10,000 commissioned in 1986 by the 'Togo Coastal Erosion Project' (Rossi, 1989; Blivi, 1993a,b) was used to define recent trends in barrier beach face evolution. The historical evolution of some of the most unstable zones was determined from old maps, miscellaneous documents, written colonial reports and oral accounts.

In an attempt to map areas of consolidated beachrock that would protect the barrier front against marine erosion (Rossi, 1989; Blivi, 1993a), more than 70 shallow $(<15 \mathrm{~m})$ boreholes were drilled. These were highly concentrated along the beachfront zone within $700 \mathrm{~m}$ of the sea (Blivi, 1993a), giving a rather unrepresentative coverage of the entire barrier system. These boreholes, together with $\log$ descriptions of numerous other deeper (up to $40 \mathrm{~m}$ ) boreholes drilled on the barrier front and on the shoreface during the construction of the port of Lomé (Fig. 1) in the 1960s, were used to determine the shallow stratigraphy of the external part of the barrier system in Togo. Unfortunately, the log descriptions of the deeper boreholes only give grain size variations and miscellaneous summary information on facies. This, together with the dearth of radiocarbon ages from these deposits (see below) constrains their stratigraphic interpretation. This interpretation is, however, supported by the higher resolution obtained from contiguous deposits in Benin (Lang et al., 1995; Anthony et al., 1996).
Characterisation of barrier-front beach and backbarrier lagoonal dynamics was derived from field surveys. These included observations of wave breaker characteristics, barrier overwash, and tidal inlet processes. Observations were carried out on surficial bedforms as well as shallow $(<1 \mathrm{~m})$ internal facies from trenches. Grain size parameters were measured and heavy minerals analysed to determine sand source zones. Longshore sand drift volumes were determined from short-term $(<1 \mathrm{yr})$ accretion rates updrift of groynes and from monitoring of annual accretion rates updrift of the Lomé harbour breakwater.

\section{The sand barrier-lagoon complex}

\subsection{Environmental context}

The sand barrier system (Fig. 2) with its associated lagoonal and lacustrine system is fed by several small coastal rivers and by the Volta River in Ghana. The Volta drains a predominantly sandstone catchment and a wide variety of other lithologic terranes covering an area of $390,000 \mathrm{~km}^{2}$. The Volta River discharge varied between a low of $1000 \mathrm{~m}^{3} / \mathrm{s}$ in the dry season and a high of over $6000 \mathrm{~m}^{3} / \mathrm{s}$ in the wet season before completion of the Akosombo Dam (Fig. 1) in 1961, only $60 \mathrm{~km}$ upstream from the sea. Because of the decrease in rainfall that has affected West Africa since the 1960s, the spillways of this dam have hardly functioned since 1975, thus diminishing considerably discharge downstream of the dam. The Volta Delta covers an area of around $5000 \mathrm{~km}^{2}$. The sand load brought down annually by the river to its delta before dam construction has been estimated at about $1 \times 10^{6} \mathrm{~m}^{3}$ (Delft Hydraulics, 1990). Much of this sand load was injected into the longshore drift system via a single delta channel (Fig. 2).

The Bight of Benin coast is exposed throughout the year to constant, low- to moderate-energy $\left(H_{\mathrm{b}}\right.$ 0.5-1.5 m), long-period ( $T$ 10-15 s) Atlantic swells from a relatively narrow south to southwesterly window (Fig. 2). These generate one of the highest rates of annual unidirectional longshore sand drift in the world, with values recorded updrift of groynes and the Lomé harbour breakwater ranging from 1.2 to 


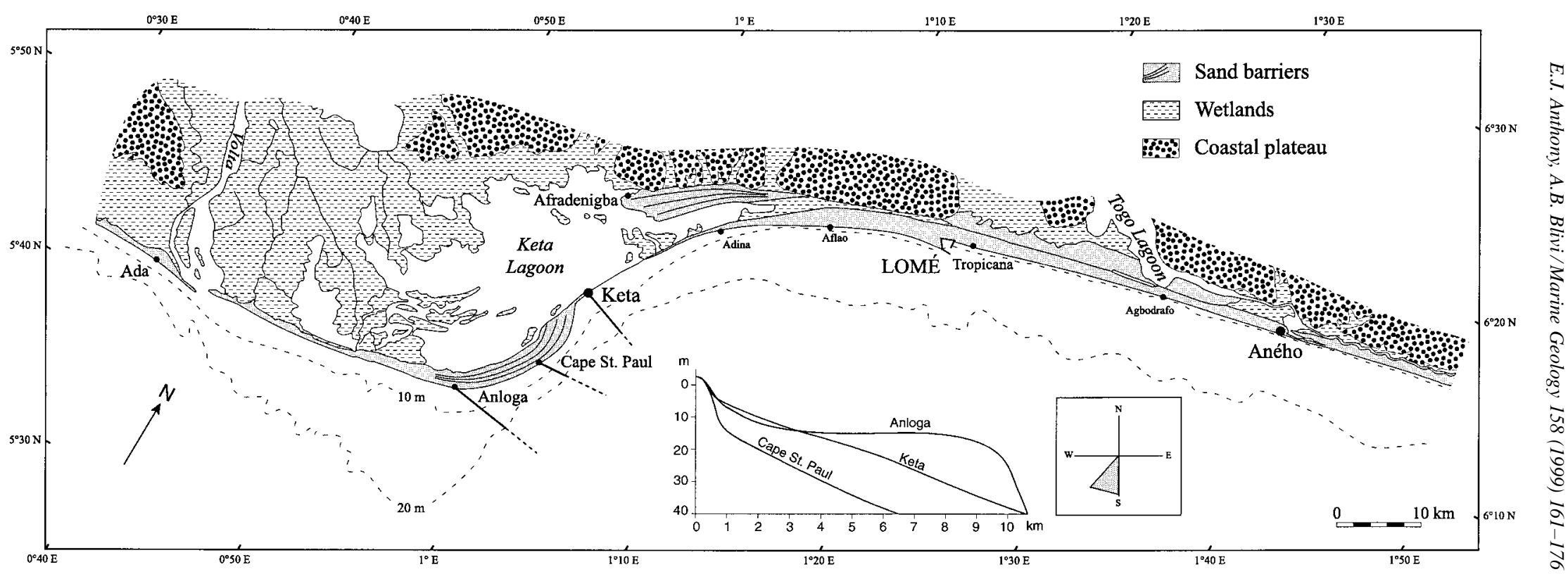

Fig. 2. The barrier-lagoon system of eastern Ghana and Togo and sites mentioned in the paper. Insets show shoreface profiles of the western Volta Delta and year-round wave approach window. 
$1.5 \times 10^{6} \mathrm{~m}^{3}$ (Rossi, 1989; Blivi, 1993a,b). The Volta Delta still constitutes the only primary source for this sand, which is derived today from reworking of delta mouth deposits downstream of the Akosombo Dam, as well as from erosion of the delta-mouth barrier, and from nearshore deltaic deposits. Tides impinging on this coast are semi-diurnal, with a mean range of about $1 \mathrm{~m}$. The mean spring tidal range is $1.45 \mathrm{~m}$ on the Ghanaian coast and increases to $1.95 \mathrm{~m}$ on the Togolese coast.

\subsection{Morphology}

The sand barrier system (Fig. 2) bounds a coastal plateau of Tertiary and Quaternary deposits capped by Pleistocene fluvial and sheetwash deposits regionally referred to as the 'Terre de Barre'. The plateau is cut by depressions and fluvial valleys occupied by marshy wetlands and lagoons. The sand barrier is a complex twin-barrier system (Fig. 3) rising 3 to $6 \mathrm{~m}$ above present mean sea level. Only in the western proximal part are the two barrier generations readily distinguishable. The inner portion is a discontinuous barrier alternating alongshore with 'headlands' of the Quaternary/Tertiary deposits bounded by inactive cliffs. In the west, it consists of a short independent set of flared ridges (Fig. 2) anchored on deltaic deposits in the Keta Lagoon. To the east, this inner barrier is a much dissected feature limited to a $37-\mathrm{km}$ stretch of marshy and lagoonal 're-entrant' coast between Lomé and Aného (Fig. 2), its distal tip ending in a wetland. The outer barrier is continuous with breaks at tidal inlets and river flooddischarge outlets, stretching from the present mouth of the Volta, near Ada (Fig. 2), to Nigeria. The two barriers are commonly separated by a wetland swale. The inner barrier disappears in the Aného area on the Togo-Benin border (Fig. 2) where the system narrows down to a single (outer) barrier cut by a small channel (Fig. 4) draining the Togo Lagoon. The outlet of this lagoon is sealed by longshore drift over much of the year. The barrier progressively widens further east in Benin.

The Bight of Benin coast is fronted by a moderately steep upper shoreface with a gradient of between $1: 20$ and 1:50 down to the $10 \mathrm{~m}$ isobath, excepting the Volta delta-mouth area where this gradient ranges from 1:80 to 1:200 (Fig. 2). The 10$11 \mathrm{~m}$ depth contour has been considered as the outer limit of significant wave action on this coast

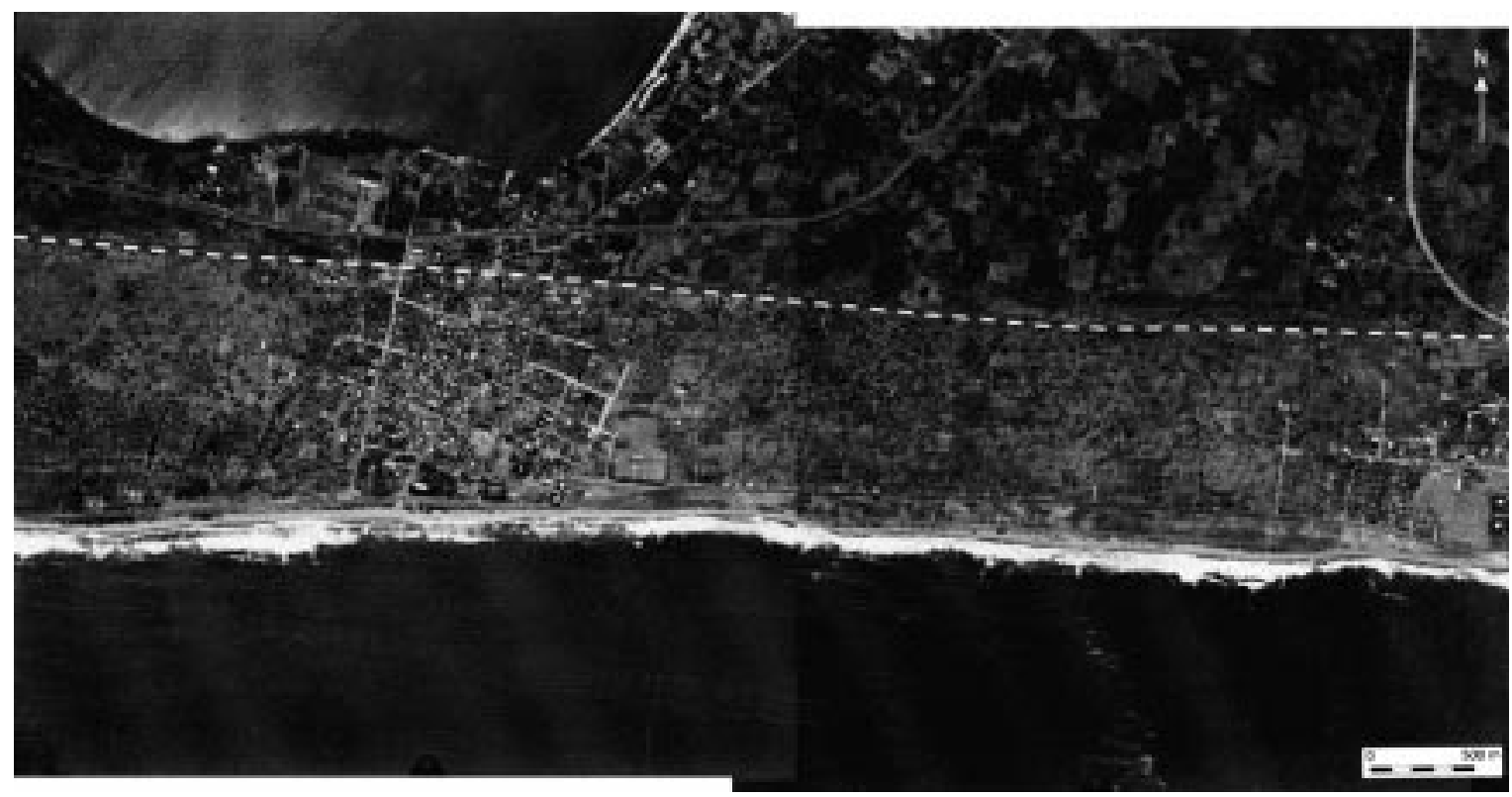

Fig. 3. Aerial photograph (1986) showing the inner barrier partly eroded by Togo Lagoon to the left, just north of the settlement of Abgodrafo (see Fig. 2) located on the outer barrier. The latter, 1-1.5 km wide in this area, is separated from the inner barrier by a mild swale highlighted by the broken white line. 


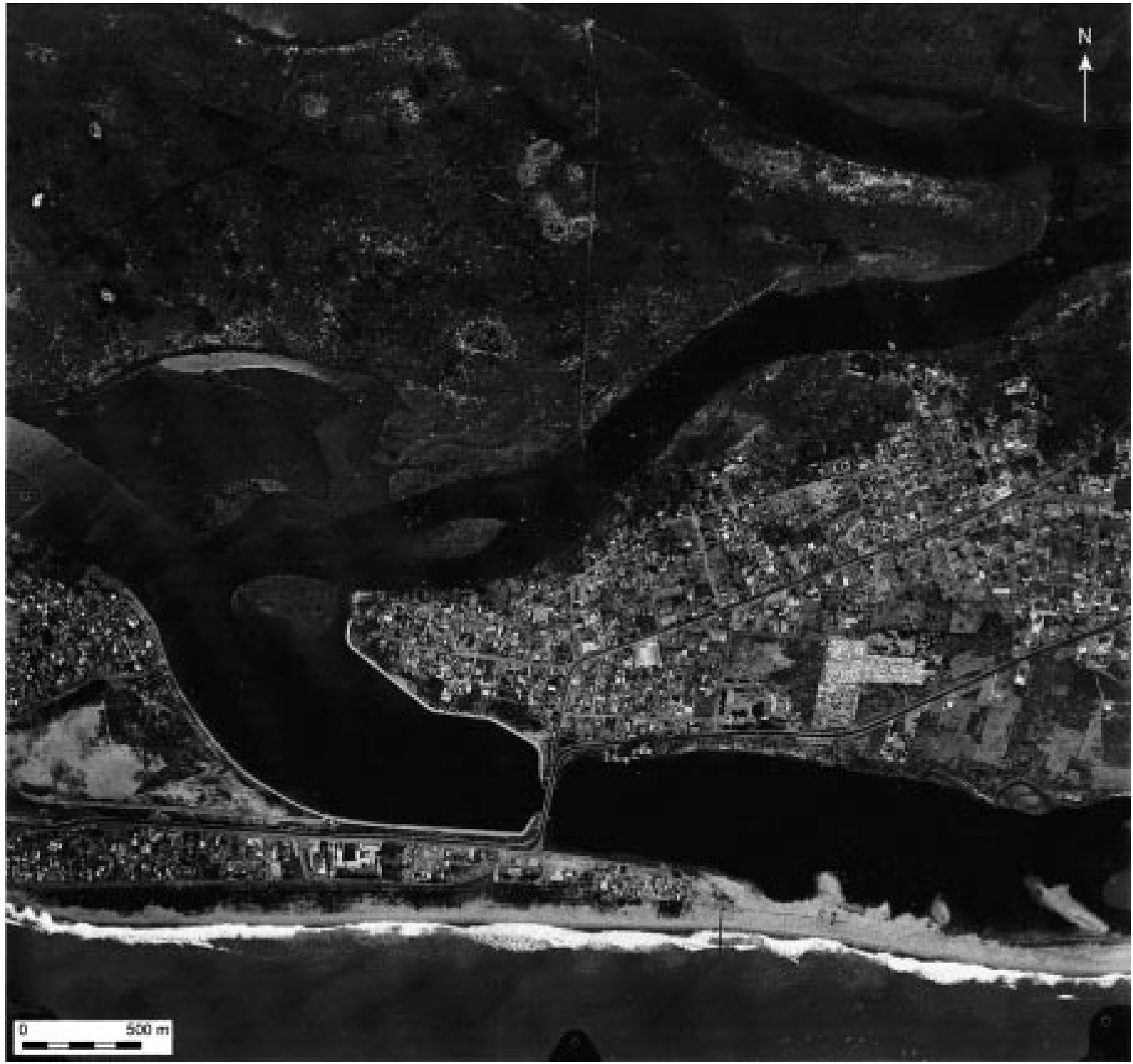

Fig. 4. Aerial photograph (1986) of the sand barrier and lagoon in the Aného inlet area. The inlet is sealed during much of the year. The narrow barrier-inlet zone (considerably eroded over the last 30 years, see text) in this area is reworked by inlet breaching and eastward migration during the late rainy season (August to November) when back-barrier lagoonal flooding becomes important.

(Rossi, 1989; Blivi, 1993a). Beyond this depth, the inner shelf exhibits a low-gradient lower shoreface of about 1:250 to 1:350 off Keta. This gradient rises sharply to 1:120 in the Cape St. Paul area, and then decreases dramatically to $1: 500$ to $1: 800$ further to the southwest off Anloga (Fig. 2), reflecting past massive deltaic shoreface progradation in this area (Dei, 1985). It should be noted that the Keta and
Cape St. Paul areas are respectively erosional and accretionary.

\subsection{Sedimentary facies}

Barrier beach and shoreface deposits range in thickness from less than $5 \mathrm{~m}$ on their landward edges to $15-20 \mathrm{~m}$ seaward. Shallow $(<15 \mathrm{~m})$ boreholes 
from the outer barrier show a unit 8-15 m thick of beach and upper shoreface sand, with local gravel patches of a variety of crystalline and sedimentary source rocks, and shelly debris. Beach sand is dominantly quartz $(>80 \%)$, medium to coarse $(0.4-1$ $\left.\mathrm{mm}, D_{50} 0.6 \mathrm{~mm}\right)$, and subangular to subrounded. Minor fractions of feldspars (up to $10 \%$ ), shelly debris $(5-15 \%)$ and heavy minerals $(1-5 \%)$ make up the rest of the sand fraction. The heavy mineral fraction shows no significant differences between the two barrier generations. It is dominated by a mixture of mature opaque minerals (e.g., andalusite, rutile, tourmaline), ferruginous weathering products (limonite) and a set of easily weatherable minerals, comprising especially garnet, epidote, amphibolite and green hornblende (Oyédé, 1991; Blivi, 1993a). Scattered glauconitic grains may reflect a contribution from the nearshore zone (Ly, 1980). In addition to sand, this facies contains up to $15 \%$ mud, derived, as in similar sand barriers elsewhere in West Africa (Anthony, 1985), from weathering of feldspars and some of the more easily decomposed heavy minerals in the initial barrier sand.

The beach/upper shoreface deposits invariably grade into a lower shoreface facies of interbedded fine sand (0.08-0.125 mm) and mud (Fig. 5), locally with shelly debris. This unit, 3-10 m thick, has been identified in almost all boreholes exceeding 10-12 m. The fine sand and mud facies (comprising no less than $50 \%$ mud) also blankets the present lower shoreface zone beyond $11 \mathrm{~m}$. The lower shoreface deposits rest on a sandy-gravel unit, 8-12 m thick, with scattered patches of shelly debris. This unit is underlain by a muddy facies with organic, shelly and wood remains, which in turn overlies a basal unit of gravel, sand and silt in some boreholes. This succession is similar to, and the deposits lie within the altitudinal range of, the better known Holocene and Pleistocene sediments in Benin (Oyédé, 1991; Lang et al., 1995; Anthony et al., 1996). The basal three units in Fig. 5 have been tentatively identified (see below) respectively as partially preserved transgressive-aggradational barrier sand, transgressive-aggradational marsh and lagoonal mud, and lowstand sheetwash-fluvial deposits. Based on the correlation with the Benin sequences, the former two are of Holocene age, and the last Late Pleistocene. Barrier development during the transgression is briefly described in the next section where emphasis will be placed on the phases of progradation and stability, following the eustatic stillstand, and on recent destabilization.

\section{Morphosedimentary evolution}

\subsection{Transgressive barrier-lagoon development}

The facies stacking described above and correlated with published work from the Bight of Benin, is schematically presented in Fig. 6. Interpretation of the Late Quaternary infill of river mouths in neighbouring Benin has shown that the basal gravel, sand and silt unit in Fig. 5 represents sheetwash-fluvial deposits that outcrop landward as the 'Terre de Barre'. These basal sediments have been interpreted as lowstand deposits that were transgressed by marsh and lagoonal mud deposited behind transgressive sand barriers during the Holocene sea-level rise (Anthony, 1995a; Lang et al., 1995). The thickness of the preserved transgressive barrier sand (Fig. 5), despite probable subsequent reworking following the stillstand (see below), suggests that significant shoreface aggradation may have been taking place during the late transgressive phase, probably fed by longshore drift from the Volta. Fig. 5 also depicts marsh and lagoonal sediments continuously underlying the transgressive barrier. This suggests rapid rates of vertical accumulation of these sediments during the transgression, as fine-grained sediments brought down by the coastal rivers, notably the Zio (Fig. 1), were trapped behind the transgressive barrier. Radiocarbon ages from fine-grained mangrove-rich sediments in the Volta Delta (Streif, 1983), shown in Table 1, and similar ages obtained by Germain (1975) in estuarine re-entrants in Benin, testify to the extensive development of mangroves and marshes associated with lagoonal mud behind such transgressive sand barriers. These ages span the late transgressive phase as well as the stillstand which occurred at about 5500 to 5000 yr B.P. The relationship between facies appears to be complex in the inner landward edges of the sand barriers, notably those bounding the Volta Delta. At Anloga (Fig. 2), the barrier rests on relatively shallow mangrove-rich lagoonal mud radiocarbon-dated at $4990 \pm 65$ yr B.P. and $5060 \pm 155$ yr B.P. (Table 1). This stratigraphic re- 

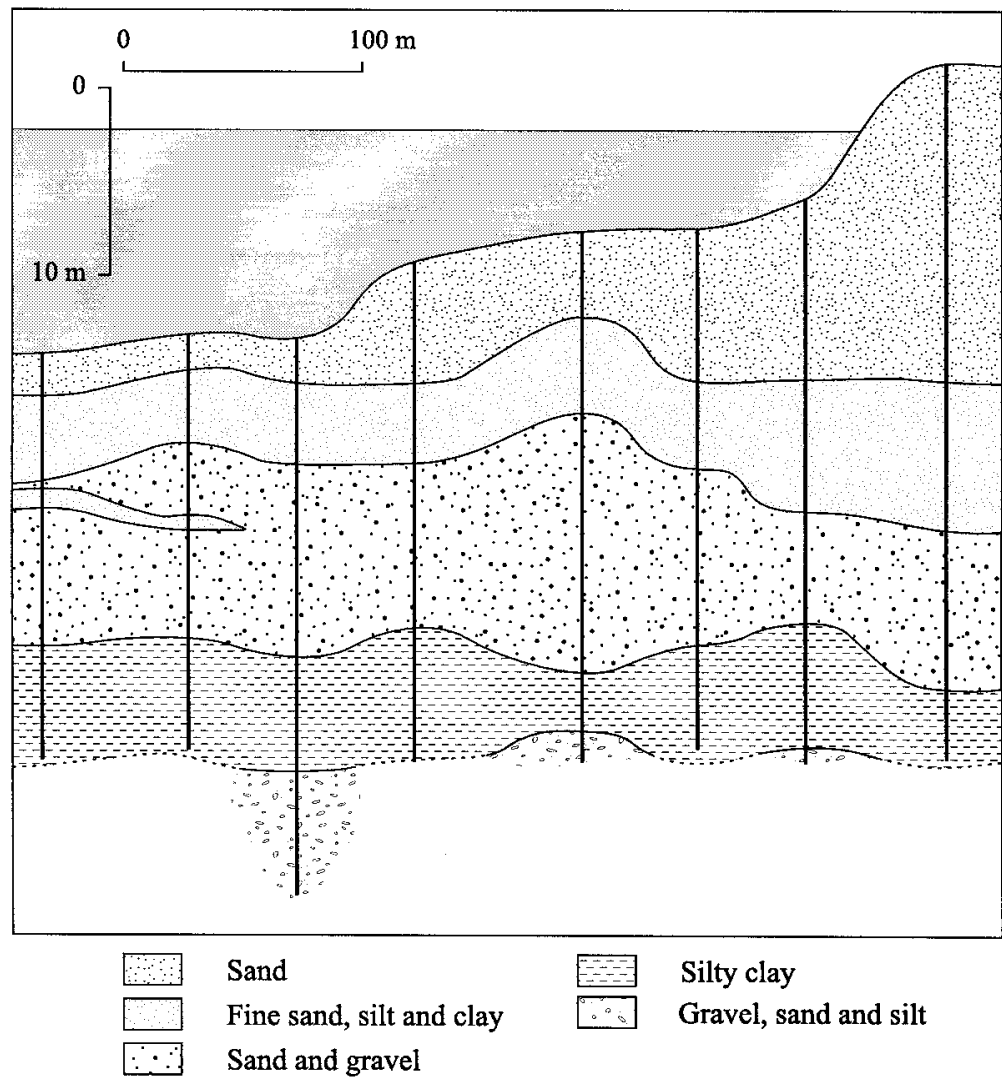

Fig. 5. Barrier front and nearshore shallow stratigraphy, showing a complex succession of five units. Lines indicate boreholes. Section runs offshore from the present site of Lomé harbour (see Fig. 2).

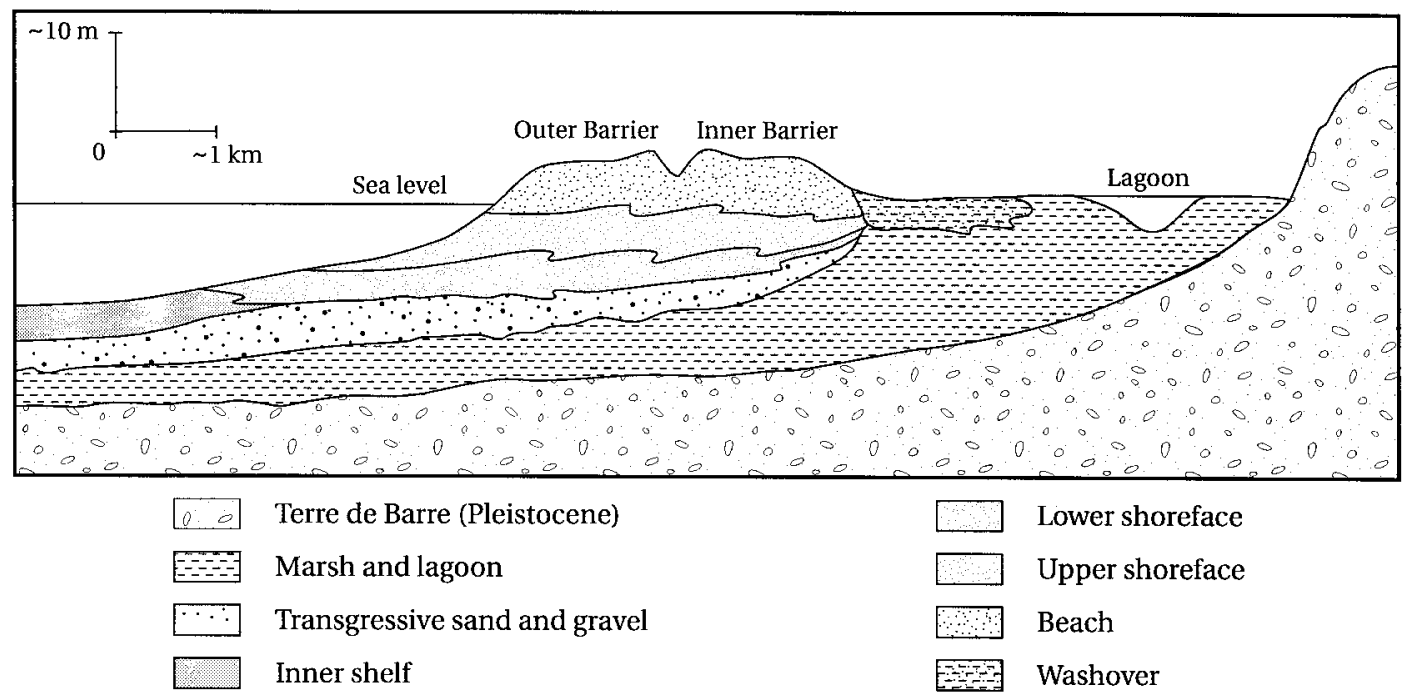

Fig. 6. Schematic interpretation of shallow barrier-lagoon stratigraphy, based on borehole data (see Fig. 5), field observations and correlation with the better known contiguous barrier-lagoon deposits in neighbouring Benin. N.B.: scale is approximate. 
Table 1

Radiocarbon ages from mangrove peat ${ }^{\mathrm{a}}$ in Ghana and beachrock $^{\mathrm{b}}$ in Togo

\begin{tabular}{lll}
\hline Age & Laboratory number & Coordinates \\
\hline $5060 \pm 155$ & Hv $9410^{\mathrm{a}}$ & $0^{\circ} 55^{\prime} 55^{\prime \prime} \mathrm{E}, 5^{\circ} 48^{\prime} 20^{\prime \prime} \mathrm{N}$ \\
$4990 \pm 65$ & $\mathrm{Hv} 9411^{\mathrm{a}}$ & $0^{\circ} 55^{\prime} 55^{\prime \prime} \mathrm{E}, 5^{\circ} 48^{\prime} 20^{\prime \prime} \mathrm{N}$ \\
$6245 \pm 100$ & $\mathrm{Hv} 9412^{\mathrm{a}}$ & $0^{\circ} 58^{\prime} 42^{\prime \prime} \mathrm{E}, 6^{\circ} 01^{\prime} 30^{\prime \prime} \mathrm{N}$ \\
$5765 \pm 80$ & $\mathrm{Hv} 9413^{\mathrm{a}}$ & $0^{\circ} 57^{\prime} 12^{\prime \prime} \mathrm{E}, 6^{\circ} 03^{\prime} 26^{\prime \prime} \mathrm{N}$ \\
$6955 \pm 85$ & $\mathrm{Hv} 9414^{\mathrm{a}}$ & $0^{\circ} 57^{\prime} 12^{\prime \prime} \mathrm{E}, 6^{\circ} 03^{\prime} 26^{\prime \prime} \mathrm{N}$ \\
$6320 \pm 100$ & $\mathrm{Hv} 9415^{\mathrm{a}}$ & $0^{\circ} 30^{\prime} 49^{\prime \prime} \mathrm{E}, 5^{\circ} 46^{\prime} 53^{\prime \prime} \mathrm{N}$ \\
$6330 \pm 105$ & $\mathrm{Hv} 9416^{\mathrm{a}}$ & $0^{\circ} 30^{\prime} 49^{\prime \prime} \mathrm{E}, 5^{\circ} 46^{\prime} 53^{\prime \prime} \mathrm{N}$ \\
$3800 \pm 90$ & Ly $3919^{\mathrm{b}}$ & $1^{\circ} 18^{\prime} 05^{\prime \prime} \mathrm{E}, 6^{\circ} 8^{\prime} 55^{\prime \prime} \mathrm{N}$ \\
$2890 \pm 100$ & Ly $3920^{\mathrm{b}}$ & $1^{\circ} 18^{\prime} 05^{\prime \prime} \mathrm{E}, 6^{\circ} 8^{\prime} 55^{\prime \prime} \mathrm{N}$ \\
\hline
\end{tabular}

${ }^{\mathrm{a}}$ From Streif, 1983. ${ }^{\mathrm{b}}$ From Amieux et al., 1989.

lationship provides a middle Holocene age for the start of barrier progradation in this area. It also suggests washover and aggradational processes in the waning phase of the transgression, before the onset of barrier progradation. Stratigraphic data from similar coastal lagoons in Benin (see below) show that these lagoons were shallow re-entrant sinks filled with mud that is overlain seaward by tidal, and wave and washover deposits (Anthony, 1995a; Anthony et al., 1996). Table 1 includes two other radiocarbon ages obtained from barrier-front beachrock exposed as a result of erosion in Togo (Amieux et al., 1989). Their significance will be discussed later.

\subsection{Progradation}

The plan-view pattern and spatial distribution of the inner barrier in Ghana and Togo (Fig. 2) suggest that early progradation was strongly controlled by antecedent topography, with marked longshore variations in wave refraction. The sediment for this segmented inner barrier was supplied by cliffs in the earliest phase of progradation, by partial reworking of transgressive barrier sand on the shelf, and especially by longshore transport from the Volta. By providing sediments for rapid beach and shoreface progradation over earlier transgressive sediments, the Volta probably played a significant role in promoting preservation of the transgressive-aggradation sandy and muddy facies on the shelf (Fig. 5). The prograding delta-mouth barrier whose muddy substrate was dated by Streif (1983) at Anloga may have been contemporaneous with the segmented inner barrier in Togo. The development of the latter barrier resulted in the impounding of the Togo Lagoon (Fig. 2).

Once progradation of this inner barrier resulted in shoreline regularization, the succeeding phase of coastal development involved the emplacement of the more continuous outer barrier directly linked to the Volta mouth. The updrift (westward) narrowing of the proximal part of this outer barrier (Fig. 2) is synonymous with the progressive delta-ward migration of this proximal hinge point. This probably suggests the establishment of a highly efficient drift alignment and transition to an economy of massive sediment sourcing by the Volta. The barrier types characterising this phase of coastal development are identified in Fig. 7. Much of the delta front and the bight coast exhibits a regressive single or double barrier. We surmise that the Volta delta-mouth barrier zone labelled 3 (?) in Fig. 7 has been essentially a 'stationary' barrier sector of active through-drift of sand from the Volta. The longshore barrier patterns may be defined in terms of morphostratigraphic classifications (Thom, 1984a,b; Reinson, 1984). The

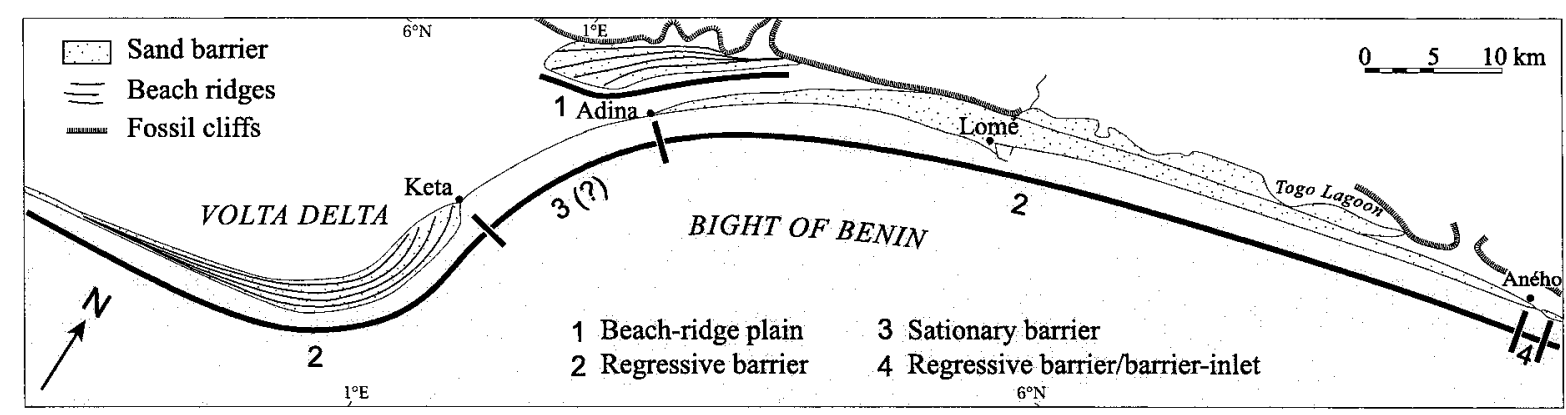

Fig. 7. Simple morphologic-stratigraphic subdivisions of the western Bight of Benin barrier system prior to recent $\left(>10^{2}\right.$ yr $)$ large-scale modifications. 


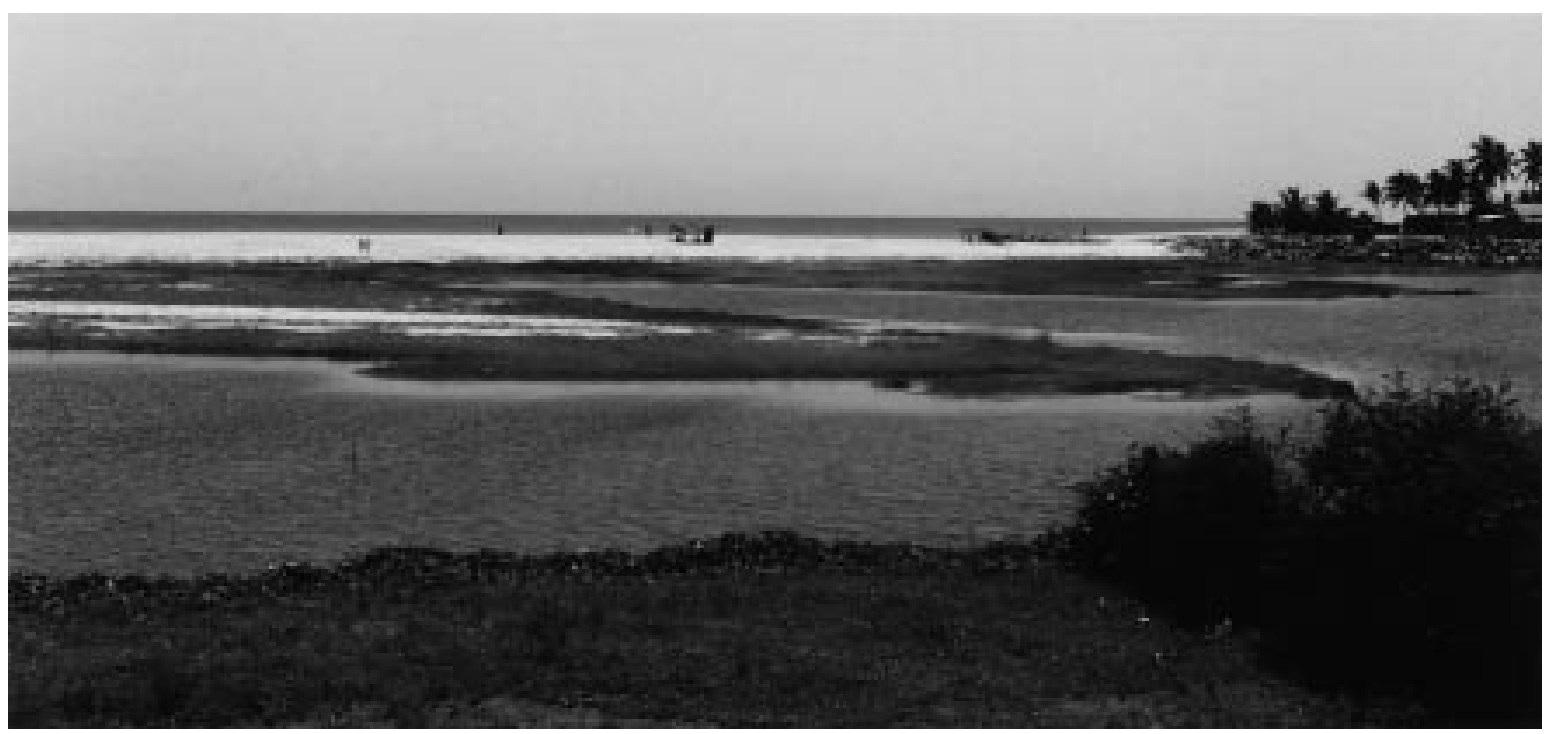

Fig. 8. Ground photograph of the narrow barrier-inlet and lagoon sector of Aného with washover fan and flood-tidal delta sands colonized by Ipomoea pes-caprae (April 1995).

regressive (prograded) barrier bounding much of the coast of Togo evolves into a very short ( $\sim 2 \mathrm{~km})$ "hybrid' system that shows both progradation and barrier-inlet reworking in the Aného inlet area (Fig. 7). To the east, in Benin, it becomes once again a simple regressive barrier. The subsurface facies in the Aného inlet area have not been identified. However, the surficial morphology of the barrier in this area, which is constantly reworked by inlet breaching, migration and sealing, comprises reworkable washover and flood-tidal delta sand (Fig. 8), in addition to beach and inlet channel sand.

The Aného area therefore differs from the rest of the regressive Togo barrier in that it exhibits a single outer regressive-barrier-inlet system (Fig. 4) with a short lagoonal arm formed by limited longshore migration of the Aného inlet. The establishment of an inlet system in this area reflected the necessity to balance increasing pressure alongshore from lagoonal and stream drainage. The marshes and the lagoon diverted eastward by the twin barrier system are finally partially drained seaward in this area where overall barrier width (progradation) has been lessened by inherited coastal morphology (in the form of cliff-bound, weakly protruding, coastal plateau 'headlands' (Fig. 2)). This situation was reinforced by early cessation of barrier progradation due to longshore drift conditions (see below). In spite of the strong longshore drift, eastward inlet migration was limited by both cessation of barrier progradation over the last 3000 years, as discussed below, and the strongly seasonal character of inlet functioning. Prior to recent beach defence works, the Aného inlet was sealed by a narrow stationary barrier (Figs. 2 and 4) more than eleven months a year. The barrier was generally briefly breached at the height of the wet season in October by both overwash processes due to stronger swell and pressure from the severely flooded extensive back-barrier lagoonal system.

\subsection{Long-term stability}

The few radiocarbon ages from the barrier front show a phased pattern of barrier progradation from eastern Ghana to Togo. The ages from the Volta Delta near Ada and Anloga (Fig. 2) suggest little net progradation of the delta-mouth barrier over the past 5000 to 6000 years. While attesting to the post-middle Holocene age of the overlying barrier sand, and to no net progradation, they in no way indicate barrier stability since $5000 \mathrm{yr}$ B.P. The past behaviour of the barrier in this area remains speculative. In spite of the massive sand supply from the Volta to the Bight of Benin, the barrier front 
shows no significant progradation since around 3800 yr B.P. in Togo, as suggested by the two ages from exposed beachrock outcrops separated by almost 900 years (Table 1). These were exposed following barrier erosion of up to $200 \mathrm{~m}$ between 1967 and 1988 (Rossi, 1989; Blivi, 1993a). Two similar but unpublished radiometric ages of $3500 \pm 100 \mathrm{yr}$ B.P. and $3400 \pm 100$ yr B.P. from cemented shell beds exposed by erosion at Aflao and near Adina (Fig. 2) have also been communicated to us (G. Rossi, pers. commun., March 1998). Ages of around 2000 to $1500 \mathrm{yr}$ B.P. from the Benin seafront further east (Lang and Paradis, 1984) confirm this trend, with earlier cessation of progradation occurring in Togo near the Volta sand pump. These few ages therefore suggest relatively rapid progradation over a fairly short time (5000 to 3000 yr B.P.), especially in Togo, once longshore drift conditions became favourable to large-scale eastward advection of Volta sand. The ensuing phase of net long-term longshore stability in Togo and Benin probably stemmed from some sort of equilibrium involving shoreline orientation, the nearshore profile and the hydrodynamic regime (Anthony, 1995b). The final sink for this sand is the eastern end of the Bight of Benin in Nigeria.

Overall, therefore, some of the barrier morphostratigraphic variations, the occurrence of a single or double barrier, and differences in net progradation in Togo, have been due to longshore drift gradients. These gradients were determined by inherited coastal configuration, antecedent topography, drainage and sediment supply modulation from the Volta. The inner barrier is absent, and the outer barrier a 'hybrid' regressive-inlet system, where coastal plateau bands jut out, constraining available progradational space, or, to borrow a term employed in modern sequence stratigraphy, 'accommodation space', as in the Aného inlet area (Fig. 7). It is significant to note that while antecedent topography varied alongshore, progradational or accommodation space was uniformly constrained seaward by strong longshore drift, once an equilibrium drift-alignment was attained.

\subsection{Recent destabilization}

The long-term state of equilibrium of the barrier front in the western Bight of Benin is attested by the abundance of Portuguese and other European settlements and forts starting from the 16th century (Blivi, 1993a). It is doubtful indeed whether massive installations such as forts would have been constructed in now strongly eroding areas like Keta. This long-term state of equilibrium has been perturbed by modern dam and coastal installations. The construction of the Akosombo Dam on the Volta river in 1961 resulted in a drastic reduction in sand supply to the Bight of Benin coast (Ly, 1980), thus necessitating reworking of the delta sand stocks to fulfil longshore drift budgets. It is worth noting in passing that no coastal impact study was carried out before the construction of this dam. There is, however, clear evidence, outlined below, that coastal erosion along the delta-mouth barrier itself antedated dam construction, as Ly (1980) suggested. In particular, the necessity to satisfy the strong longshore drift budget towards Togo has resulted in considerable reworking of the Volta delta-mouth barrier segment itself, including the nearshore zone, threatening coastal settlements, notably Keta (Fig. 9), a once flourishing colonial port. From an analysis of historical records, both Kumapley (1989) and Blivi (1993a) have suggested that this now highly threatened area has been one of fluctuating erosion and accretion since at least 1860. Since the mid-1880s, a realistic estimate of net erosion of this area is probably close to $1 \mathrm{~km}$ (Kumapley, 1989). Old maps show that this deltamouth barrier stretched continuously up to Aného. We have suggested above that the now highly eroded Keta area was a stationary barrier that acted as a zone of through-drift between the Volta mouth and the regressive barrier in Togo (Fig. 7), prograding or undergoing erosion in response to changing pulses in drift in the past. This through-drift zone of relative equilibrium has evolved into a zone of cell segmentation (Fig. 10) and modification of barrier morphosedimentary dynamics.

The most likely reason for this dramatic erosion is that direct sand supply from the Volta mouth over the last century has not been sufficient to compensate for strong drift supply to the rest of the Bight of Benin. This situation has been exacerbated since the 1960s by the construction of the Akosombo Dam, as various lines of evidence in the lower Volta channel and delta mouth have shown (Anthony and Blivi, unpubl. data). Drift requirements have been satisfied 


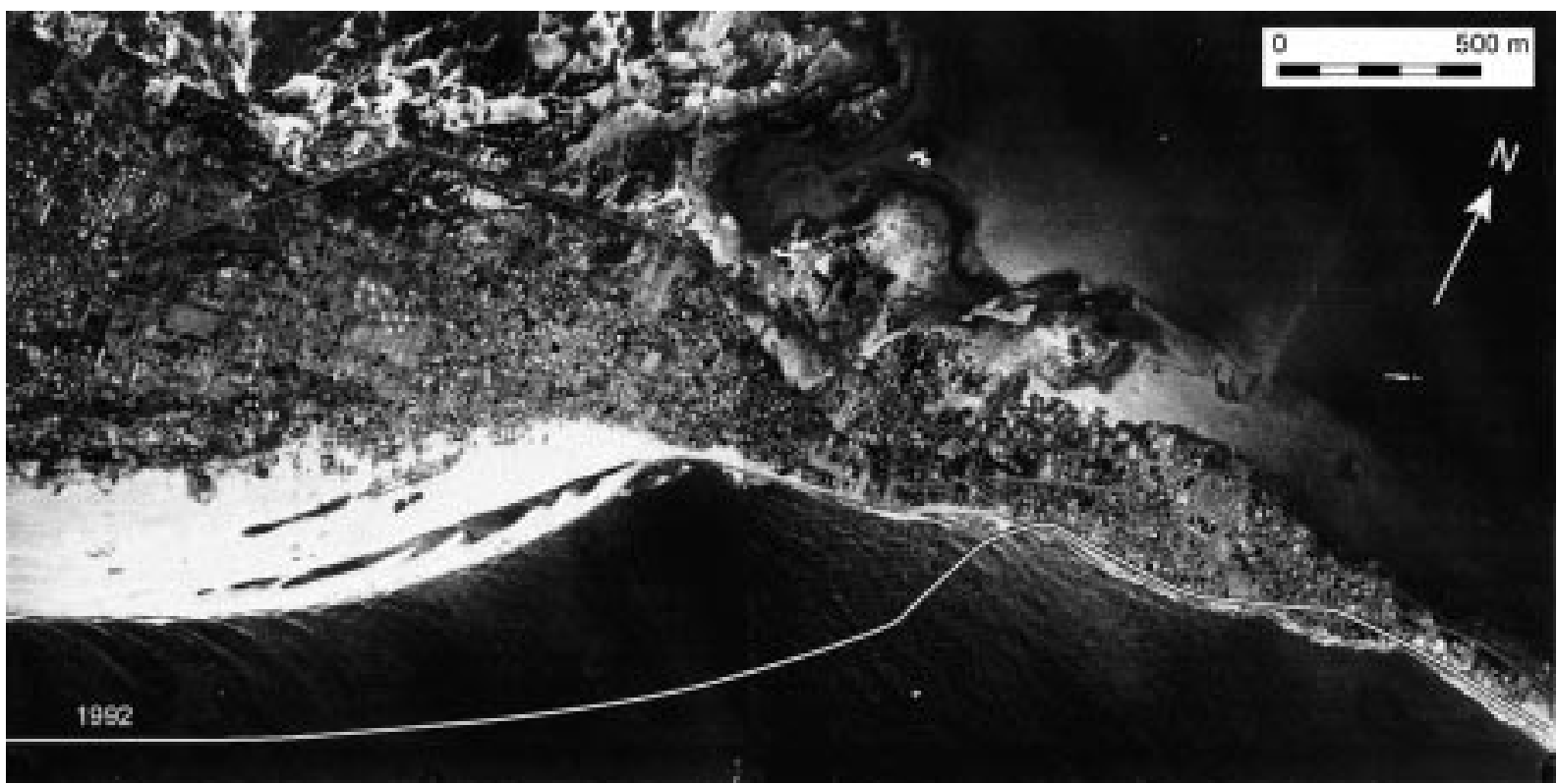

Fig. 9. Aerial photograph (1986) of the barrier in Keta, showing the locus of recent massive sedimentation and equally spectacular downdrift erosion that has destroyed much of this once flourishing port. The successive eastward sand deposition, illustrated by precise levelling and determination of the shoreline in 1992, is in fact now affecting the once eroding sector of accelerated longshore drift. Eventually, this swash-aligned sector of accumulation may become less so as the accumulation sector migrates eastward, thus leading to lesser sequestering of sand and better through-drift towards Togo.

by substantial barrier retreat and shoreface erosion, leading to the relatively planar shoreface profile off Keta (Fig. 2). As erosion has proceeded to satisfy sand drift requirements, the most severely 'cannibalised' drift acceleration zone (Fig. 11) between the prograding Volta barrier and the Togolese coast is now characterised by a narrow $(<100 \mathrm{~m}$ wide) eroding transgressive barrier subject to overwash during the summer months of strong swell. In places, muddy backbarrier marshes are now exposed along the beach.

Cell segmentation has involved substantial sequestering of sand by the distal portion of what has become a distinct Volta delta-mouth prograding beach-ridge spit complex (Fig. 9), especially since the 1960s. We have estimated the amount of sand locked up in this prograding spit between 1968 and 1996 at $20 \times 10^{6} \mathrm{~m}^{3}$. Once the initial through-drift

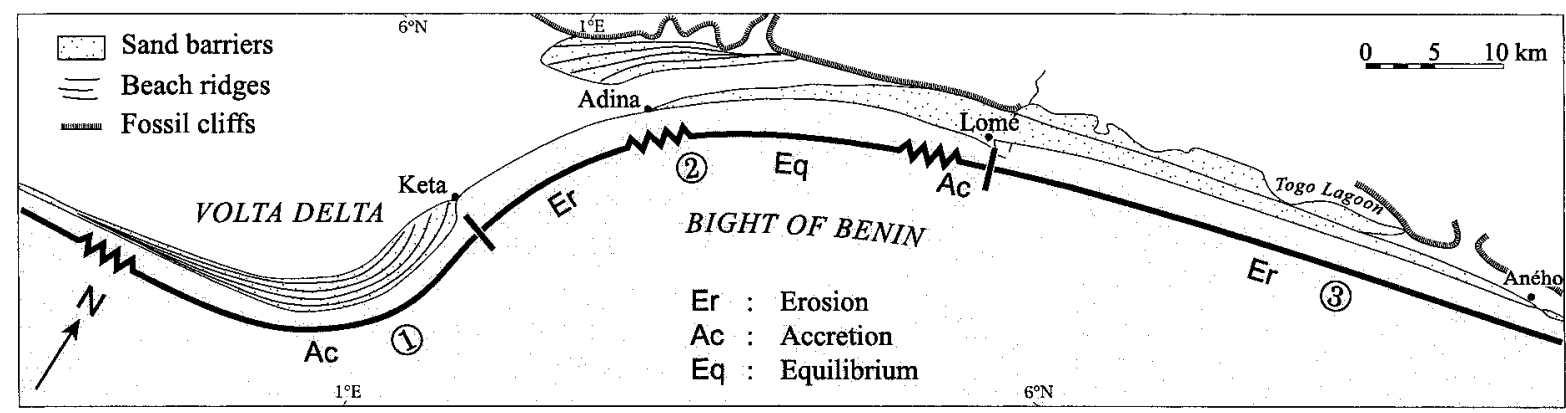

Fig. 10. Summary of recent changes in longshore barrier front dynamics resulting from both modulation of fluvial and deltaic sand supply by the Volta and construction of Lomé harbour. These changes have involved segmentation of the former unique sediment cell into three shorter cells. 

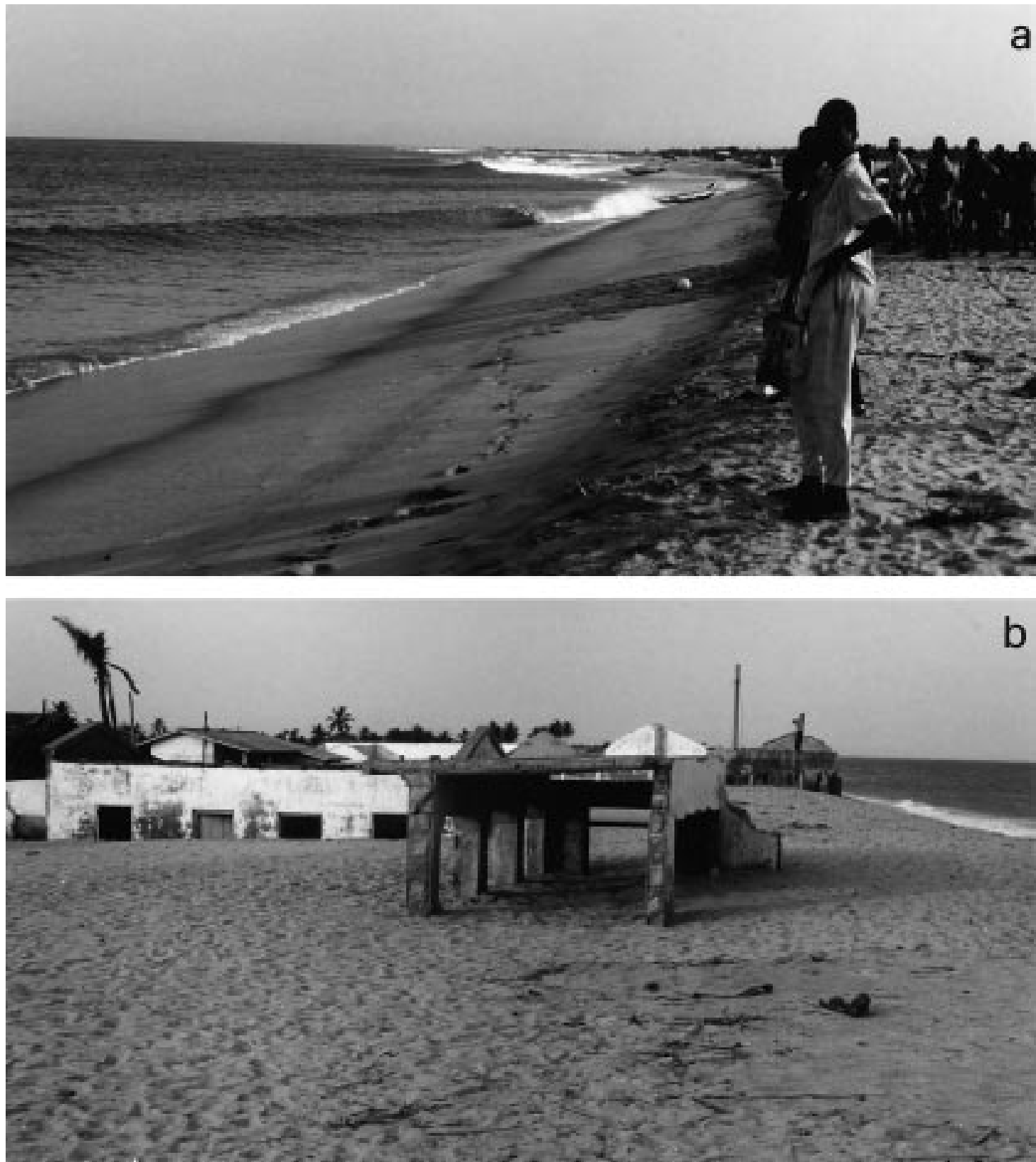

Fig. 11. Ground photographs showing the zone of strong eastward drift acceleration in Keta (A). Note the acute $\left(\sim 30^{\circ}\right)$ angle of incident swell and the steep, narrow reflective beach. (B) Erosion of the Keta barrier front. Buildings are progressively buried and subsequently eroded by washover and landward sand transfer towards the Keta Lagoon (to the left) as the barrier becomes narrower (April 1995).

configuration in this zone was altered by the sediment budget imbalance evoked above, this forced further refraction, amplifying cell segmentation, and resulting in the instauration of a swash-alignment associated with sequestering of sand by this new spit complex. The sand influx into this spit zone attains up to $0.75 \times 10^{6} \mathrm{~m}^{3}$ a year. It involves progradation of lobes of coarse to medium Volta sand over a silty 


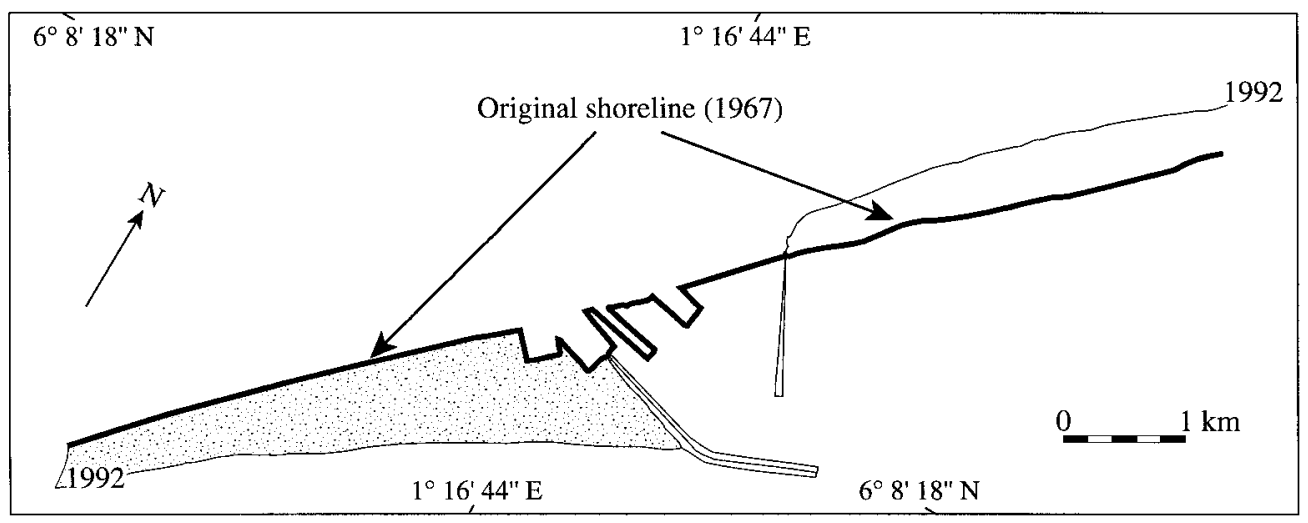

Fig. 12. Shoreline changes on either side of Lomé harbour breakwater between 1967 and 1992. Erosion east of the breakwater has been attenuated by longshore exposures of highly indurated beachrock that acts as natural breakwaters.

shoreface at a depth of around $10 \mathrm{~m}$ (Rossi, 1989), resulting in the relatively steep shoreface off Cape St. Paul.

A recent feature of this spit growth is that the formerly highly eroded proximal zone of the drift acceleration zone, or drift 'pulse', is now being protected by this spit, as may be inferred from the 1992 contour of this spit (Fig. 9). More recent field work shows even greater spit accumulation. This situation is interesting as it probably heralds a shift towards a less swash-aligned distal spit zone. This should allow for eastward 'leakage' of some of the Volta sand, rather than quasi total sequestering, thus alleviating erosion further east.

The rest of the Togolese barrier shows two major cells. The deepwater port of Lomé, inaugurated in 1967, has had an even more dramatic role in perturbation of the longshore sediment dynamics (Fig. 12) than the distant Akosombo Dam may have had. West of Lomé harbour, the erosional sector up to Adina is relayed by a sector of overall net shoreline stability (Fig. 10). Beyond this sector, progradation increases steadily to attain a maximum of close to $1 \mathrm{~km}$ in the last 30 years just updrift of the main western harbour breakwater (Fig. 12). Beyond the breakwater, the segmented drift cell once again comprises an erosional sector that affects the Togolose coast up to the Benin border. Erosion has resulted in considerable damage to the former main coastal international highway and in the landward relocation of numerous former coastal villages and fishing communities. This erosion has necessitated the emplacement of an expensive groyne field in 1988 to protect Aného and a nearby phosphate export facility. The shoreline stability assured by this groyne field has exacerbated, as one should expect, barrier erosion downdrift in western Benin. It also results in a longer period of opening of the Aného inlet (up to four months a year), inducing greater saltwater intrusion into the hitherto essentially freshwater lagoonal system of Togo.

\section{Discussion and summary}

On the basis of morphostratigraphic characteristics, Reinson (1984) proposed three barrier endmember types - regressive, transgressive and barrier-inlet - based on the dynamic behaviour of the barrier shoreline and the inlets that are sometimes associated with such barriers. Thom (1984a,b) similarly proposed a variety of sand barrier types incorporating these three end-members, mostly based on examples from Australia and temperate North American settings. These, and other syntheses on barriers (e.g., McCubbin, 1982; Galloway and Hobday, 1985; Davis, 1994), highlight the complexity of barrier coasts inasmuch as the latter generally exhibit morphological expressions and show facies arrangements controlled by a combination of numerous factors. Sea level determines the overall barrier morphostratigraphic characteristics at long time scales (hundreds to thousands of years) and is therefore implicit in the terminology of identification of such barrier end-members. However, sediment budgets 
and sediment supply patterns are also fundamental in fulfilling the dynamics of regressive or transgressive barrier systems, inasmuch as the sediment supply may or may not be sufficient to fill coastal accommodation space created by sea-level rise in the course of barrier initiation and maintenance. Furthermore, the importance accorded to tidal inlets in such classifications highlights in part the geologic and geomorphic significance of back-barrier drainage, and in some cases, longshore drift.

The sand barrier system of eastern Ghana and Togo stratigraphically comprises basal transgressive and surficial regressive facies whose superposition reflects sea-level control, strongly modulated by sediment supply. With the switch from transgression to stillstand, the sediment supply factor and, more specifically, longshore sediment transport dynamics assumed greater control on barrier development and evolution. Following this stillstand, the system developed from an essentially regressive (progradational) to a stationary (synonymous with cessation of progradation) barrier, although it exhibits elements of a 'hybrid' system incorporating transgressive and barrier-inlet facies both in time and space. It thus combines several elements of the barrier types identified by Thom (1984a,b) and Reinson (1984).

Drift-aligned barriers on open coasts such as the Bight of Benin may thus exhibit complex spatial and temporal changes in morphology, and locally in stratigraphic expression, in response to changes in sand transport gradients. Despite (but also by virtue of!) the important sand supply capacity on this coast due to the nearby Volta Delta, both shore-normal and longshore variations in progradation have resulted. The causes for these variations included inherited coastal morphology, expressed here as 'sand accommodation space', and pulses in through-drift of sand from the Volta controlled initially by longshore differences in wave refraction. As this barrier accommodation space was filled by Volta sand, this earlier stage of barrier development was followed by the development and maturing of a single major bight sediment cell from the initial smaller cells. Although the sand supply volume alongshore remained consistently high, net progradation diminished considerably or ceased, probably as early as $3400 \mathrm{yr}$ B.P. in Togo, as an equilibrium alignment allowing for through-drift of Volta sand to the rest of the Bight of Benin occurred. These conditions of drift equilibrium have been perturbed in the Volta Delta area by an imbalance, exacerbated by dam construction on the Volta, between deltaic sand supply and the strong drift requirements. The result has been dramatic erosion of parts of the delta-mouth barrier, and damage to a once flourishing coastal settlement. This recent imbalance and the associated barrier and shoreface erosion have forced changes in refraction and sediment cell dynamics, generating, in particular, cell segmentation and massive updrift sequestering of sand by a recent deltaic spit complex. This has exacerbated erosion further east. In Togo, construction of a deepwater port in 1967 did not pay enough attention to the potential impacts on the morphosedimentary dynamics of the coastal system. In both these cases, segmentation of the former single major sediment cell characterising the 400-km-long Bight of Benin coast has been accompanied by differential longshore erosion, progradation or equilibrium, and by the reactivation of regressive and transgressive barrier dynamics in places.

\section{Acknowledgements}

Fieldwork for the senior author, and for A.B. Blivi's PhD thesis was funded by the French Ministère de la Coopération. We express our thanks to Georges Rossi for discussions and for providing us with various unpublished data. Thanks also to the Lomé Port Authority for access to their borehole logs and unpublished reports. We wish to thank Richard A. Davis, James Shulmeister, Marie-Hélène Ruz, and Journal Editor-in-Chief David Piper for their constructive review and suggestions for improvement. Denis Marin is thanked for his limitless patience and meticulousness in preparing the illustrations.

\section{References}

Amieux, P., Dalongeville, R., Bernier, P., De Medwecki, V., 1989. Cathodoluminescence of carbonate-cemented Holocene beach rock from the Togo coastline (West Africa): an approach to early diagenesis. Sediment. Geol. 65, 261-272.

Anthony, E.J., 1985. Geomorphology, water table and soil relationships in Holocene beach ridges in southern Sierra Leone. Catena 12, 167-178. 
Anthony, E.J., 1995a. Sedimentology and sequence stratigraphy of a tropical, microtidal, coastal plain estuary, the Ouémé, Benin. IAS 16th Regional Meeting of Sedimentology, Aix-lesBains, 24-26 April, 1995, Publications de l'Association des Sédimentologistes Français, Paris 22, Abstract Book, p. 6.

Anthony, E.J., 1995b. Beach-ridge progradation in response to sediment supply: examples from West Africa. Mar. Geol. 129, 175-186.

Anthony, E.J., Lang, J., Oyédé, L.M., 1996. Sedimentation in a tropical, microtidal, wave-dominated coastal-plain estuary. Sedimentology 43, 665-675.

Blivi, A.B., 1993a. Géomorphologie et dynamique actuelle du littoral du Golfe du Bénin (Afrique de l'Ouest). Ph.D. Thesis, Université Michel de Montaigne, Bordeaux, 458 pp. (unpubl.).

Blivi, A.B., 1993b. Morphology and current dynamics of the coast of Togo. Geo-Eco-Trop 17, 25-40.

Davies, J.L., 1980. Geographical Variation in Coastal Development, 2nd ed. Longman, London, 212 pp.

Davis, R.A., 1994. Barrier island systems - a geologic overview. In: Davis, R.A. (Ed.), Geology of Holocene Barrier Island Systems. Springer-Verlag, Berlin, pp. 1-46.

Dei, A., 1985. Ghana. In: Bird, E.C.F., Schwartz, M.L. (Eds.), The World's Coastline. Van Nostrand Reinhold, New York, pp. 585-600.

Delft Hydraulics, 1990. National and regional aspects of coastal erosion in the Bight of Benin. Project 6607.43.94.155, European Development Fund, Brussels.

Galloway, W.E., Hobday, D.K., 1985. Terrigenous Clastic Depositional Systems. Springer-Verlag, Berlin, 423 pp.

Germain, P., 1975. Contribution à la connaissance du Quaternaire récent du littoral dahoméen. Bull. Assoc. Sénégal. Etude Quat. Afr. 44/45, 33-45.

Kumapley, N.K., 1989. The geology and geotechnology of the Keta basin with particular reference to coastal protection. Proc., KNGMG Symp. Coastal Lowlands, Geology and Geotechnology, pp. 311-320.
Lang, J., Paradis, G., 1984. Le quaternaire margino-littoral béninois (Afrique de l'Ouest). Synthèse des datations au Carbone 14. Palaeoecol. Afr. Surrounding Islands 16, 65-76.

Lang, J., Anthony, E.J., Oyédé, L.M., 1995. Late Quaternary sediments in incised coastal valleys in Benin: a preliminary sequence-stratigraphic interpretation. Quat. Int. 29/30, 31-39.

Ly, C.K., 1980. The role of the Akosombo Dam on the Volta river in causing erosion in central and eastern Ghana (West Africa). Mar. Geol. 35, 323-332.

May, J.P., Tanner, W.F., 1973. The littoral power gradient and shoreline changes. In: Coates, D.R. (Ed.), Coastal Geomorphology. University of New York, Binghampton, pp. 43-60.

McCubbin, D.G., 1982. Barrier-island and strand-plain facies. In: Scholle P.A., Spearing, D.R. (Eds.), Sandstone Depositional Environments. American Association of Petroleum Geologists, Tulsa, pp. 247-79.

Oyédé, L.M., 1991. Dynamique sédimentaire actuelle et messages enregistrés dans les séquences quaternaires et néogènes du domaine margino-littoral du Bénin (Afrique de l'Ouest). Ph.D. Thesis, Université de Dijon, Université du Bénin, 302 pp. (unpubl.).

Reinson, G.E., 1984. Barrier-Island and associated strand-plain systems. In: Walker, R.G. (Ed.), Facies Models. Geoscience Canada, 2nd ed., pp. 119-140.

Rossi, G., 1989. L'érosion du littoral dans le Golfe du Bénin: un exemple de perturbation d'un équilibre morphodynamique. $\mathrm{Z}$. Geomorphol., N.F. Suppl. Band 73, 139-165.

Streif, H., 1983. Die Holozäne Entwicklung und geomorphologie der Küstenzone von Ghana. Essener Geogr. Arb. 6, 1-27.

Thom, B.G., 1984a. Transgressive and regressive stratigraphies of coastal sand barriers in southeast Australia. Mar. Geol. 56, 137-158.

Thom, B.G., 1984b. Sand barriers of eastern Australia: Gippsland - a case study. In: Thom, B.G. (Ed.), Coastal Geomorphology in Australia. Academic Press, Sydney, pp. 233-261. 